\title{
Gorontalo
}

Journal of Government and Political Studies

Volume 3 - NO. 1 - April 2020

P-ISSN: 2614-2120 E-ISSN: 2614-2104

\section{Factors Influencing Citizen Satisfaction in Getting Public Service (Case Study: The Service User of The Investment and One Stop Service Agency of Tanah Bumbu Regency In 2018)}

\author{
Muhammad Iqbal ${ }^{1}$ \\ Indriani Mahbubah² \\ Ali Akbar 3 \\ Yunita Elianda 4 \\ Master Program of Government Affairs and Administration 134 \\ International Program of Government Affairs and Administration ${ }^{2}$ \\ Universitas Muhammadiyah Yogyakarta \\ Muhammad_iqbal.2013@fisipol.umy.ac.id \\ mahbubahindriani@gmail.com \\ ali.akbar.pasca17@mail.umy.ac.id \\ yunita.elianda.psc17@mail.umy.ac.id
}

Received: December 28, 2019 Reviewed: April 20, 2020

Accepted: April 20, 2020

\begin{abstract}
The present study explained factors influencing citizen satisfaction service in the Investment and One-Stop Service Agency of Tanah Bumbu Regency. In particular, this research analyses the level of citizen satisfaction and the extent to which Awareness, Rules, Organizational, Income, Skill-Ability, and Service Facility Factor influence Citizen Satisfaction. This study uses a mixed methodology with a sequential explanatory strategy. Using the incidental sampling with Slovin's Formula to calculate the number of samples is 93 respondents. The quantitative data were analyzed by the SmartPLS 3.0 program. The findings showed that the level of citizen satisfaction is included in the category "Satisfied". Furthermore, the variable of Citizen Satisfaction is influenced by variables of Awareness, Rules, Organizational, Income, Skill-Ability dan Service Facility Factor for 70,5\%. Whereas Awareness, Rules, Organizational, and Skill-Ability Factor has a significant influence on Citizen Satisfaction. Besides, Income and Service Facility Factor do not have a significant influence on Citizen Satisfaction.
\end{abstract}

Keywords: Citizen Satisfaction, Public Service, One-Stop Service, One-Stop Service Agency

\section{INTRODUCTION}

Nowadays, demands arise for the government to provide public services oriented to society and responsive to the needs of the society. This is in accordance with the paradigm of public administration in the perspective of 'New 
Public Service' where the role of government is 'serving' the public with the aim of improving service quality (Yusriadi, 2018: 8). However, the demand for these services usually far exceeds the government's ability to fulfill them that will lead to citizen dissatisfaction with the services received. This is proved with an article entitled 'Rapot Merah Pelayanan Publik di Indonesia' quoted from https:// tirto.id in 2016, the Head of the Ombudsman of Republic Indonesia, Amzulian, concluded that "the low level of public services still appears with the high practice of the illegal levies and bribes". Furthermore in 2017, quoted from https://www.aa.com.tr (2017), it is known that the low level of public service is still the biggest problem for Indonesia and there is a need to increase the use of information technology so that public services are accountable and free of Corruption, Collusion and Nepotism $(\mathrm{CCN})$ actions. Likewise quoted from http://kompas.com, throughout 2017, the Ombudsman received 7,999 public reports that are divided into ten types of maladministration on public service.

A surveys conducted by World Bank also showed bad report on public services in Indonesia. Based on the World Bank report related to the Ease of Doing Business (EoDB). Throughout the four years of Joko Widodo and Yusuf Kalla's administration, Indonesia's EoDB ranking has been increased quite significantly but has not been able to raise Indonesia's position neither at the global nor the Southeast Asian level. In EoDB 2019, Indonesia fell one rank to the 73rd position (with a score of 67.96) from 190 countries. Meanwhile, at the Southeast Asia level, the competitiveness of EoDB in Indonesia is still lagging behind, stagnating still as in previous years, in 6th position among other Southeast Asian member countries. Indonesia is under Singapore (ranked 2 with a score of 85.24), Malaysia (ranked 15 with a score of 80.6), Thailand (ranked 27 with a score of 78.45), Brunei Darussalam (ranked 55 with a score of 72.03), and Vietnam (ranked 69 with a score of 68.36) (https://databoks.katadata.co.id, 2018). This position is still far from what had been targeted by President Jokowi, which is a 40th ranked on a global level.

The quality of public services in Indonesia is expected to improve while the issuance of Law No. 25 of 2009 dated 18 July 2009 regarding Public Services. This law has become a momentum and concrete steps from the government to bring the best services to the society. Nowadays, society or business world expects to be able to meet service needs, especially administrative services from the government in one place. One of the strategies implemented by the government was the establishment of One-Stop Service at both the central and regional levels. This is in accordance with the Presidential Regulation of the Republic of Indonesia Number 97 of 2014 concerning the Implementation of OneStop Integrated Services and Number 91 of 2017 concerning Acceleration of Business Implementation. The implementation of good public services at the regencies/cities level is also the responsibility of the government for society (Iqbal, 2019).

In the context of regional autonomy, the existence of One-Stop Service in regencies/cities is expected to encourage economic growth through increased investment by giving greater attention to the micro, small and medium enterprises actors. The aim to be achieved is to improve the quality of public services that lead to citizen satisfaction. Besides, it gives wider access to society to obtain public services. Service implementation at the Investment and OneStop Service Agency of Tanah Bumbu Regency must provide the best service to 
businessmen or service users. The success of service delivery is determined by the level of satisfaction of service users. The satisfaction of service users can be achieved if they obtain services in accordance with what are they needed and expected. Thus, based on the explanation above, to ensure the realization of public expectations for good public services. The researcher feels the importance of assessments related to the level of citizen satisfaction and analysis related to factors that can be influence citizen satisfaction in getting public services by conducting studies at the Investment and One-Stop Service Agency in Tanah Bumbu Regency. This citizen satisfaction assessment is one of the benchmarks for service units to conduct evaluations to improve the quality of public services.

\section{RESEARCH METHODS}

This study uses a quantitative and qualitative research approach (mixed methodology) with a sequential mix method, namely a sequential explanatory strategy. A 'sequential explanatory strategy', means that quantitative and qualitative approach are used in a different stage (Creswell, 2014). In this strategy, the first stage is to collect and analyze quantitative data by distributing questionnaires to the respondent to examine the citizen satisfaction level on public service and factors influencing citizen satisfaction in getting service at the Investment and OneStop Service Agency in Tanah Bumbu Regency. Then, the second stage is supported by qualitative data obtained from the related informant where the data is collected as complementary information that will be used to strengthen the analysis of previous quantitative data finding in the preparation of research findings. In mixed method research, two forms of data are combined in the analysis of design through data fusion, data merging or data sticking (Creswell, 2014).

The population of the study is service users who are getting public service of the Investment and One-Stop Integrated Service Agency in Tanah Bumbu Regency in the year 2018. The sampling technique used is a non-probability sampling technique with incidental sampling. Incidental sampling is a technique for determining samples based on coincidence, that is, anyone who incidentally meets with a researcher can be used as a sample if viewed by the person who happened to be found it is suitable as a source of data (Sugiyono, 2016). Then, the researcher used Slovin's Formula to calculate the number of samples is 93 service users.

\section{RESULT AND DISCUSSION}

\subsection{The Level of Citizen Satisfaction In Getting Public Service}

The level of citizen satisfaction in getting public service in The Investment and One-Stop Service Agency of Tanah Bumbu Regency which can be seen in table 3: the level of citizen satisfaction by index value. It shows the level of citizen satisfaction as the service user of the public service based on the priciples or indicators of Simplicity, Openness, Efficiency, Economic, Fairness, and Timeliness. The index value is obtained from the mean of the respondent's answer based on the Likert Scale assessment. The result shows the index value obtained from each indicator is included in the interval value from 3.41 to 4.20 with the category "Satisfied". The indicator or principle of the fairness got the highest score, meanwhile the efficiency got the lowest score. It means that the principle of fairness in public service is the principle that has the most optimal of 
its application compared to other principles, that make citizen satisfied in getting public services at the Investment and One-Stop Service Agency of Tanah Bumbu Regency.

Among the six principles, there are some aspects that are often complaints or barriers for service users in the licensing process, which are cost, time and requirements of licensing. According to the results of this research, four principles related to these three aspects have a low index value compared to the two other principles. The four principles, namely Economical, Simplicity, Timeliness and the Efficiency which cover the three aspects have got the lowest score. These results are in line with those written by Juniarso. The data supported is according to Juniarso (in Yusriadi, 2018: 98) that the obstacles that are usually complained of by service users who want to apply for licensing are the cost, time and requirements of licensing.

a. Licensing costs: The cost of obtaining permits is very burdensome for small business actors and the amount of licensing cost is often not transparent. The reason for a large cost is because the applicant does not know the official cost for obtaining permits, and also because of illegal levies and pander actions that happened.

b. Time: the time required to administer permits is relatively long because the process is complicated, there is no clarity when the permit is completed and the licensing process depends on the pattern of each regional work unit bureaucracy. For example, in the management of the length of time needed to issue the results of technical recommendations of technical agencies.

c. The same requirements and are asked repeatedly for various types of permits, the requirements set are often difficult to obtain and there are several requirements that cannot be fulfilled especially by small entrepreneurs.

\subsection{Factors Influencing Citizen Satisfaction In Getting Public Service}

The explanation was following the three stages of PLS analysis which is the outer model testing, inner model testing, and hypothesis testing. The outer model testing is done by evaluating the outer model with its reflection indicators. There are three criteria of indicators of reflection, namely convergent validity, discriminant validity and composite reliability. The output of the loading factor that will be used as a basis for measuring and knowing the results and interpretation of the outer loading which can be seen in figure 2: loading factors. The each value on the indicator does not have a value of less than 0.50 , so the next that can be done is by evaluating the model.

The first and second criteria, namely convergent validity and discriminant validity can be seen from the results of the score from the outer model, namely the value of AVE and loading factor. Validity of data that can be seen from AVE and loading factor has a value limit for a data that can be said to be valid. The AVE and loading factor value is said to be valid if the score is more than 0.50 and if the score is less than 0.50 then the data cannot be said to be valid. Validity test results in study show that all the questions in each research variable consisting of Awareness Factor, Rules Factor, Organizational Factor, Income Factor, Skill-Ability Factor and Service Facility Factor have a value of loading factor bigger than 0.50 and most variables research have AVE value bigger than 0.50 which can be seen in table 4 : convergent validity and discriminant validity. 
Thus, it can be concluded that all questions in all research variables are declared valid or have fulfilled the convergent and discriminant validity.

In addition to the validity test, reliability tests were also measured using two criteria, namely Composite Reliability and Cronbach's Alpha from the indicator block that measured the construct. Constructions are declared reliable if the Composite Reliability and Cronbach's Alpha value are above 0.70 (Ghozali \& Latan, 2014). The Composite Reliability and Cronbach's alpha Output can be seen in table 5: Composite Reliability and Cronbachs Alpha. Based on Composite Reliability and Cronbach's Alpha values or outputs shows that the value of each construct is above 0.70. Thus, it can be concluded that each construct in the estimated model has good reliability. The reliability test result shows that all research variables have a Composite Reliability value and Cronbach's Alpha more than 0.70. Therefore, it can be concluded that all the questions contained in each research variable in the questionnaire are declared reliable and the questionnaire can be used to retrieve research data.

Furthermore, the second ananlysis stage, the inner model testing is done to see the relationship between constructs, significance values and R-square of the research model. The structural model is evaluated using $\mathrm{R}$-square for the dependent construct of the t-test and the significance of the structural path parameter coefficients. In assessing the model with PLS it is started by looking at the R-square for each Latent Dependent variable. Based on table 6: Output Rsquare shows the R-square value of the Citizen Satisfaction with Public Service variable was obtained at 0.705 , which can be explained that variable of Citizen Satisfaction with Public Service is influenced by variables of Awareness Factor, Rules Factor, Organizational Factor, Income Factor, Skill-Ability Factor and Service Facility Factor for $70,5 \%$. If it is associated with the Rule of Thumb for R Square testing according to (Ghozali \& Latan, 2014), the structural model that has an R-square result (R2) of 0.67 indicates that the model is "good", R-square (R2) of 0.33 indicates that the model "Moderate", and R-square (R2) of 0.19 indicates that the model is "weak". Then it can be concluded that the variables that affect the Citizen Satisfaction with Public Service variable have a "good" level of influence because they have an R-square result (R2) of 0.705 and it can be categorized as a "good" model.

Furthermore, the third analysis stage, hypothesis testing between variables namely exogenous variables towards endogenous variables $(\gamma)$ and endogenous variables towards endogenous variables $(\beta)$ is done by bootstrap resampling method. The test statistics used is t statistics or t tests. The comparison t value in this study was obtained from table $t$. The test is significant if the value of Tstatistic is $>1.96$ and $P$ values is $<0.050$. (Ghozali \& Latan, 2014). Hypothesis testing is done by looking at the output path coefficient from the results of bootstrap resampling which can be seen in figure 3: output boothstrapping and tables 7: hypotheses testing.

The findings indicated that the Awareness Factor, Rules Factor, Organizational Factor, and Skill-Ability Factor has a significant influence on citizen satisfaction with Public Service. Meanwhile, the Rules Factor and Service Facility Factor do not have a significant influence on Citizen Satisfaction with Public Service. Explanation of the results of each hypotheses can be specified as follows. 
a. The awareness factor has a significant influence on citizen satisfaction in getting public service with $\mathrm{p}$-value is less than 0.05 and $\mathrm{t}$-statistic is bigger than 1.96. Therefore, $\mathrm{H} 1$ in this study is accepted. The data is supported by the findings that the researcher found on the field that awareness can bring service povider to sincerity carrying out a task that is their responsibility. The service provider awareness of its position and duties serves as a baseline that will underlie the actions of service providers. If the service provider is aware of his position or duty as a public servant, then they will always be service-oriented and care about citizen satisfaction when he serving. Awareness can lead service provider to paying attention and prioritizing the interests of the service user in the service process that will affect citizen satisfaction. That is because when the services desired by the service user can be completed in accordance with what they expect or even exceed what they expect, the service user will feel satisfied with the services they obtain. This finding is in accordance with the statement by Sedarmayanti (2009) stated that Satisfying customers (service users) is the responsibility of all parties, customers must be given the best service and as optimal as possible. It means that the awareness factor has a significant influence on citizen satisfaction. It means that the awareness factor has a significant influence on citizen satisfaction.

b. The rules factor does not have a significant influence on citizen satisfaction in getting public service with $\mathrm{p}$-value is bigger than 0.05 and $\mathrm{t}$-statistics is less than 1.96. Therefore, $\mathrm{H} 2$ in this study is rejected. The data is supported by the findings that the researcher found on the field that service users tend not to pay attention to the good or bad of rules that exist, as well as to understand or not the officers to the rules that exist in the service agency. All regulations are good or bad, it does not have a influence on citizen satisfaction, because they tend not to know the benchmarks of good or bad a rules and tend to focus only on what things are needed for completion of the permit. Likewise, the officers' understanding with the rules in service agency does not have influence on citizen satisfaction, because there tends to be no obligation for service officers to understand all existing rules, but only required to understand the basic rules which are their main duties or responsibilities. It means that the rules factor does not have a significant influence on citizen satisfaction. This finding rejected by findings from Mulyono (2017).

c. The organizational factor has a significant influence on citizen satisfaction in getting public service with p-value is less than 0.05 and t-statistic is bigger than 1.96. Therefore, H3 in this study is accepted. The data is supported by the findings that the researcher found on the field that there is a need for good cooperation and coordination to get the citizen satisafaction. The organization's working arrangements and mechanisms can produce adequate services, the organization becomes an effective tool in an effort to achieve goals, in this case, good and satisfying services. According to Fadillah (in Hasbullah 2013: 32) that the presence of public organizations is a tool to meet needs and create public satisfaction. Public service performance can be said to be successful if it is able to realize what is the main task and function of the organization concerned. For this reason, organizations and employees who carry out activity must always be 
oriented and concentrate on what is their duty. Public organizations must be able to build a shared commitment to creating a vision in improving the service process so that there is a need for good cooperation and coordination. This finding is supported by the previous research which was conducted by Rohmad (2017) that there is a positive and significant influence of coordination on citizen satisfaction. It means that organizational factor has a significant influence on citizen satisfaction.

d. The Income factor has a significant influence on citizen satisfaction in getting public service with p-value is less than 0.05 and t-statistic is bigger than 1.96. Therefore, $\mathrm{H} 4$ in this study is supported. The data is supported by the findings that the researcher found on the field that the action of illegal levies and panders in the permit proccess will makes service user disappointed by the services provided by service providers which at the end of the process causes the service applicant to feel unsure and not even trust that the service will give a clear service. It provides a reason for the service user not to be satisfied with the services provided by the Service Agency. The inadequate income or salary received by employees for the minimum needs of employees can lead to the irregularities of employees' action in the implementation of services to obtain an advantage. It needs honesty in every service effort given to the service user, this is in accordance with Zeithaml et al. (in Hardiyansyah, 2018) stated that the expected service and perceived service is determined by credibility: trustworthiness, believability, the honesty of the service provider, where the expected service that is in accordance with the perceived service will make service user feel satisfied with the service. It means that income factor has a significant influence on citizen satisfaction.

e. The data is supported by the findings that the researcher found on the field that the skillability of the officer that is good, have quality and in accordance with the competencies required by the agency and add with the work experience will provide optimal performance in the implementation of public services. This will make the use of services trust in the ability of officers to provide quality and satisfying services. It means that the skillability factor has a significant influence on citizen satisfaction. This finding supported by the finding of previous research conducted by Arif (2013) that the variable of the capability of staff has a positive and significant influence on the level of user satisfaction of a one-stop service. This is in accordance with Zeithaml et al. (in Hardiyansyah, 2018) stated that the expected service and perceived service is determined by competence: possession of required skill.

f. The service facility does not have a significant influence on citizen satisfaction in getting public service with $\mathrm{p}$-value is bigger than 0.05 and $\mathrm{t}$ statistics is less than 1.96. Therefore, H6 in this research is rejected. The data is supported by the findings that the researcher found on the field that the service users tend to be more concerned with the quality of the system and service processes than the existing service facility. Users of service at agency tend not to give priority to the complete public service facility, they tend not to give attention to the complete or not the work facility of agency and they have been not utilize optimally either the complaint service facility nor the information service facility that have facilitated, especially for the 
complaint and information online facility, they were surer to ask the front officer directly. That means the service facility factor does not have a significant influence on citizen satisfaction. Thus this finding rejected by findings from Sartini, Minarsih \& Wulan (2016), and Haryanto (2013) that there is a positive and significant influence of service facilities on citizen satisfaction.

\section{CLOSING}

The findings in the study show that the level of citizen satisfaction in getting public service in the Investment and One-Stop Service Agency of Tanah Bumbu Regency is included in the category "Satisfied" with the accumulated index value of 3.88. Furthermore, citizen satisfaction with public service has an R-square value of 0.705 and it can be categorized as a "good" model (based on Rule Thumb for testing R Square by Ghozali \& Latan) which can be explained that the variable of Citizen Satisfaction with Public Service is influenced by variables of Awareness Factor, Rules Factor, Organizational Factor, Income Factor, Skill-Ability Factor dan Service Facility Factor for 70,5\%. Whereas factors influencing citizen satisfaction in getting public service are Awareness Factor, Rules Factor, Organizational Factor, and Skill-Ability Factor. Besides, Income Factors and Service Facility Factor has not a significant influence on Citizen Satisfaction in getting public service. Awareness Factor, Rules Factor, Organizational Factor, and Skill-Ability Factor has a significant influence on citizen satisfaction in getting public service with $\mathrm{p}$-values is less than 0.05 and $\mathrm{t}$-statistics is bigger than 1.96. Meanwhile Income Factor and Service Facility Factor do not have a significant influence on citizen satisfaction in getting public service with $\mathrm{p}$-values is bigger than 0.05 and t-statistics is less than 1.96. The following are some aspect that should be improving based on results of this study.

a. Efficient service: the Investment and One-Stop Service Agency are advised to pay more attention to service efficiency, related to the integration between the burden of requirements with the length of time and the costs incurred by users of the service, whether in obtaining permits with or without technical agency recommendations.

b. Cooperation and coordination between the Investment and One-Stop Service Agency with related technical agencies: coordination and strict rules need to be more enhanced related to the implementation of the survey and timeliness in issuing technical recommendations, especially actions for applicating permits through technical agencies as intermediaries or third parties.

c. Enhancing the capacity of the Investment and One-Stop Service Agency employees, especially the operation of online service systems: the Investment and One-Stop Service Agency need to conduct training on the operation of the online service system to all employees, such as the One Single Submission (OSS) system.

d. Control of illegal levies and pander implementation: the Investment and the One-Stop Service Agency must control illegal levies and panders, be assertive to officers or agencies who openly carry out illegal levies and panders, provide strict regulations and sanctions related to prohibitions on illegal levies and panders and provide encouragement and awareness 
to all employees not to carry out the action of illegal levies and panders, including for technical agencies that related.

\section{BIBLIOGRAPHY}

Abdillah, W. \& Hartono, J. (2015). Partial Least Square (PLS): Alternatif Structural Equation Modeling (SEM) dalam Penelitian Bisnis. Yogyakarta: Andi Offset.

Aleḿan, R., Gutíerrez-Śanchez, R., \&Líebana-Cabanillas, F. (2017, March 24). Determinant Factors of Satisfaction with Public Services in Spain. Australian Journal of Public Administration, 77(1), 102-113

Arif, T. (2013). Faktor-faktor yang Mempengaruhi Pengguna Layanan Terhadap Kepuasan Pelayanan Perizinan di Pelayanan Terpadu Satu Pintu Badan Penanaman Modal dan Promosi Provinsi DKI Jakarta. Thesis. Jakarta: Universitas Esa Unggul.

Creswell, J. W. (2014). Research Design: Qualitative, Quantitative, and Mixed Methods Approaches, Fourth Edition. Yogyakarta: Pustaka Belajar.

Dkatadata.co.id. (2018, November 1). Di Tingkat ASEAN, Kemudahan Berbisnis Indonesia Peringkat 6.6 Retrieved https://databoks.katadata.co.id/datapublish/2018/11/01/di-

tingkatasean-kemudahan-berbisnis-indonesia-peringkat- 6 on January 2 , 2019.

Dwi, H. P. (2018). Analisis Kualitas Pelayanan Perizinan Pada Dinas Penanaman Modal dan Pelayanan Terpadu Satu Pintu Kabupaten Semarang. Undergraduate Thesis. Semarang: Universitas Dipenogoro.

Frinaldi, A. \& Embi, M. A. (2015). Influence of Public Service Quality in Citizen Satisfaction (Study in Private Hospital $Y$ in Padang, West Sumatra Province). Journal of Government and Politics, 6(1).

Ghozali, I. \& Latan, H. (2014). Partial Least Squares: Konsep, Teknik dan Aplikasi Menggunakan Program SmartPLS 3.0. Semarang: BP Universitas Diponegoro.

Haryanto, E. (2013). Kualitas Layanan Fasilitas dan Harga Pengaruh terhadap Kepuasan Pengguna Jasa Layanan pada Kantor Samsat Manado. Jurnal EMBA: Jurnal Riset Ekonomi, Manajemen, Bisnis dan Akuntansi, 1(3), 750760.

Hayati. (2017, December 20). Ombudsman: Pelayanan Publik Indonesia Rendah. Retrieved from https://www.aa.com.tr/id/budaya/ombudsman-pelayananpublik-indonesiarendah/1009689

Irawan, N. (2017). Tata kelola Pemerintahan Desa Era UU Desa. (1st Ed.). Jakarta: Yayasan Pustaka Obor Indonesia.

Islamiyanti, L. (2015). Efektifitas Penyelenggaraan Pelayanan Terpadu Satu Pintu di Kabupaten Malang. JISIP: Jurnal Ilmu Sosial dan Ilmu Politik, 4(2), 290-300.

Iqbal, M. (2019, October). Accountability in the Management of Papua's Special Autonomy Funds in Asmat Regency In the 2015-2018 Period. In Third International Conference on Sustainable Innovation 2019-Humanity, Education and Social Sciences (IcoSIHESS 2019). Atlantis Press 
Moenir, H. A. S. (2015). Manajemen Pelyanan Umum Di Indonesia. Jakarta: Bumi Aksara.

Mulyono, D. (2017). Analisis Faktor Pendorong dan Faktor Penghambat Pelaksanaan Pelayanan Publik di Kelurahan Pondok Kacang Timur Kecamatan Pondok Aren Kota Tangerang Selatan. Jurnal Mozaik, 9(2), 94100.

Rohmad, Z. (2017). Faktor-faktor yang Mempengaruhi Kepuasan Masyarakat dalam Pelayanan Publik di Dinas Kependudukan dan Catatan Sipil Kabupaten Magetan. Habitus: Jurnal Pendidikan, Sosiologi, dan Antropologi, 1(1), 24-41.

Rukayat, Y. (2017). Kualitas Pelayanan Publik Bidang Administrasi Kependudukan di Kecamatan Pasirjambu. Jurnal Ilmiah Magister Ilmu Administrasi (JIMIA), (2), 5665.

Sartini, U., Minarsih, M. M. \& Wulan, H. S. (2016). Faktor-faktor yang Mempengaruhi Kepuasan Masyarakat dalam Pengurusan Kartu Identitas Penduduk (KTP-EL) dan Dokumen Kependudukan di Kantor Dinas Kependudukan dan Pencatan Sipil Kota Semarang. Journal Of Management, 2(2).

Sugiyono. (2015). Metode Penelitian Pendididkan: Pendekatan Kuantitatif, Kualitatif, dan R\&D. Bandung: Alfabeta. Sugiyono. (2016). Metode Penelitian Kuantitatif,Kualitatif, dan R\&D. Bandung: Alfabeta.

Susila, I. (2015). Implementasi Dimensi Layanan Publik dalam Konteks Otonomi Daerah. Yogyakarta: Deepublish Publisher.

Syukri, S. H. A. (2014). Penerapan Customer Satisfaction Index (CSI) dan Analisis Gap Pada Kualitas Pelayanan Trans Jogja. Jurnal Ilmiah Teknik Industri, 13(2), 103-111.

Taher, A. P. (2016, December 2018). Rapor Merah Pelayanan Public di Indonesia. Retrieved from https://tirto.id/rapor-merah-pelayanan-publik-diindonesia-b8zr

Tashandra, Nabilla. (2017, December 29). Sepanjang 2017, Ombudsman Terima 7.999 Laporan Masyarakat. Retrieved from https:// nasional.kompas.com/read/2017/12/29/11404971/sepanjang2017-ombudsmanterima-7999-laporan-masyarakat

Wahyudianto B. P., Heri. (2015). Pengukuran Tingkat Kepuasan Masyarakat terhadap Pelaksanaan Kebijakan Pelayanan Pemerintah. Jurnal Bina Praja: Journal of Home Affairs Governance, 7(4), 331-346.

Yusriadi. (2018). Reformasi Birokrasi dalam Pelayanan Publik. Yogyakarta: Deepublish Publisher. 